\title{
Pharmaceutical Innovation: A University Experience Monge, A.
}

Rev. Virtual Quim., 2013, 5 (6), 1052-1058. Data de publicação na Web: 6 de novembro de 2013

\author{
http://www.uff.br/rvq
}

\section{Inovação Farmacêutica: A Experiência de uma Universidade}

Resumo: Os medicamentos são os bens de consumo mais importantes e resultam de atividades de pesquisa, desenvolvimento e inovação. Nos modelos tradicionais competem às Universidades as atividades de pesquisa e às Empresas aquelas de inovação. Entretanto, em um cenário mais contemporâneo, cabe a reflexão sobre o papel central destas instituições e da criação de meios de reconhecimento mútuo, que propiciem parcerias profícuas em prol do desenvolvimento de novos medicamentos. Neste cenário, será descrita a experiência da Universidade de Navarra (UN) com a criação, em 1988, do Centro de Investigação em Farmacobiologia Aplicada (CIFA), com o intuito de salvaguardar e incentivar a interfase Universidade-Empresa, visando agregar um viés inovador às atividades de pesquisa universitária e facilitar o diálogo Universidade-Empresa.

Palavras-chave: Medicamentos; inovação; CIFA; universidade-empresa.

\begin{abstract}
Pharmaceutical drugs are the most important of all consumer items produced by society and result of research, development and innovation activities. In traditional models, the universities have always done the research and the companies have carried out the innovation aspect. The modern businesses and universities recognize the need to serve society, especially with regard to drugs. The question we should reflect on is if these institutions, significantly relevant for the modern world, recognize one another and feel that they are mutually useful for their own aims. In this attempt to save this University-Company interphase, in the service of innovation, we described the experience of University of Navarra (UN) with the creation, in 1988, of the Center for Applied Pharmacobiological Research (CIFA), with the aim of providing university research with an innovating "plus" and facilitating University-Company relationships.
\end{abstract}

Keywords: Pharmaceutical drugs; innovation; CIFA; University-Company relationships.

\footnotetext{
* University of Navarra, Center for Applied Pharmacobiological Research (CIFA), 31008 Pamplona, Spain.

Mcifa@unav.es

DOI: $\underline{10.5935 / 1984-6835.20130077}$
} 


\section{Pharmaceutical Innovation: A University Experience}

\section{Antonio Monge}

University of Navarra, Center for Applied Pharmacobiological Research (CIFA), 31008

Pamplona, Spain.

* cifa@unav.es

Recebido em 5 de novembro de 2013. Aceito para publicação em 5 de novembro de 2013

\section{Introduction}

\section{Work approaches}

\subsection{Services exclusively of CIFA}

2.2. Business and Project incubators

2.3. Specialized teaching

2.4. Project administration

\section{Final Considerations}

\section{Introduction}

Pharmaceutical drugs are the most important of all consumer items produced by society. The need to improve the existing products as well as to offer patients new compounds for unresolved problems is an important objective for science.

Medicinal agents are the result of scientific research. It is necessary to point out that a drug is only produced when, after the necessary research and development processes have been carried out, innovation has been achieved. Innovation is today's key word in this field of science. Innovation is the act of putting forth a compound to serve society. Research alone, without innovation, does not produce final products.

In their traditional roles, the universities have always done the research and the companies have carried out the innovation aspect. The modern businesses and universities recognize the need to serve society, especially with regard to drugs. The question we should reflect on is if these institutions, significantly relevant for the modern world, recognize one another and feel that they are mutually useful for their own aims. Their true destinies include joint understanding and acceptance as essential partners.

From a university point of view, in a critical exam, the question to ask is whether or not the results of a given university research work have the adequate characteristics to be studied and valued by companies. In this attempt to save this University-Company interphase, in the service of innovation, the University of Navarra (UN), in 1988, started up the Center for Applied Pharmacobiological Research (CIFA), with the aim of providing university research with an innovating "plus" and facilitating University-Company relationships. 

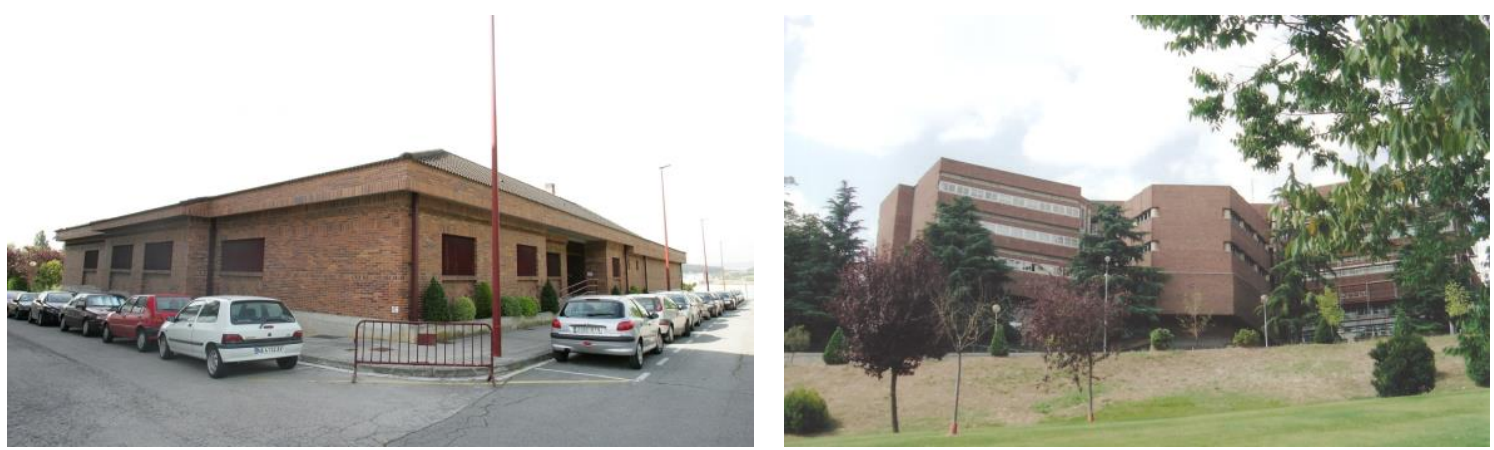

Figure 1. (Left) Center for Applied Pharmacobiological Research (CIFA), (Right) University of Navarra (UNAV)

From the very beginning, CIFA was given its own building for carrying out specific activities and for resolving diverse needs of the Faculties of Medicine, Pharmacy, and Sciences in addition to the University of Navarra Hospital, acting as interlocutor for companies in the production and management of projects in both directions, offering results to the businesses and carrying out their own projects. This union with UN centers is always produced within the principles of liberty, avoiding duplication of activities being carried out in other departments and services. The basis of the University-Company relationship is the project itself, in a modern sense, taking advantage of the possibilities of benchmarking and outsourcing provided by technology.

Four work approaches were defined, all of them within the world of drugs and related areas.

\section{1) Services exclusively of CIFA.}

2.2) Business and Project incubators

2.3) Specialized teaching.

2.4) Project administration

\section{Work approaches}

\subsection{Services exclusively of CIFA}

A series of needs which were not covered in the traditional university were defined:

\subsubsection{The use of animals in research}

In the area of pharmaceutical research, animals are an essential piece that should be used with a series of important reservations.

a) Animals will only be used in the cases in which the information that will be expectedly obtained cannot be acquired by physicochemical techniques, isolated cells, etc. The number of animals used will always be kept at a minimum, selecting those species which are considered to be the most ideal for the experiment.

b) The animals will be fully recuperated or euthanized without causing pain.

c) An ethics committee must study the experiment as well as authorize it.

d) The experimentation and conservation of the animals should permit reproducibility of the experiments, thereby needing the following: adequate rooms for housing the animals, sufficient space for the movement of all personnel, isolated quarantine areas, etc.

CIFA also permits the use of animals for practicing techniques and new approaches to be applied in human surgery. 


\subsubsection{Toxicology Services}

Toxicology is an essential piece for pharmaceutical innovation, which must be carried out perfectly, and as soon as possible within the innovation process, so as to avoid unnecessary costs and the development of inadequate products.

Toxicology studies will be carried out on cells and on animals, with decisive guaranteed quality.

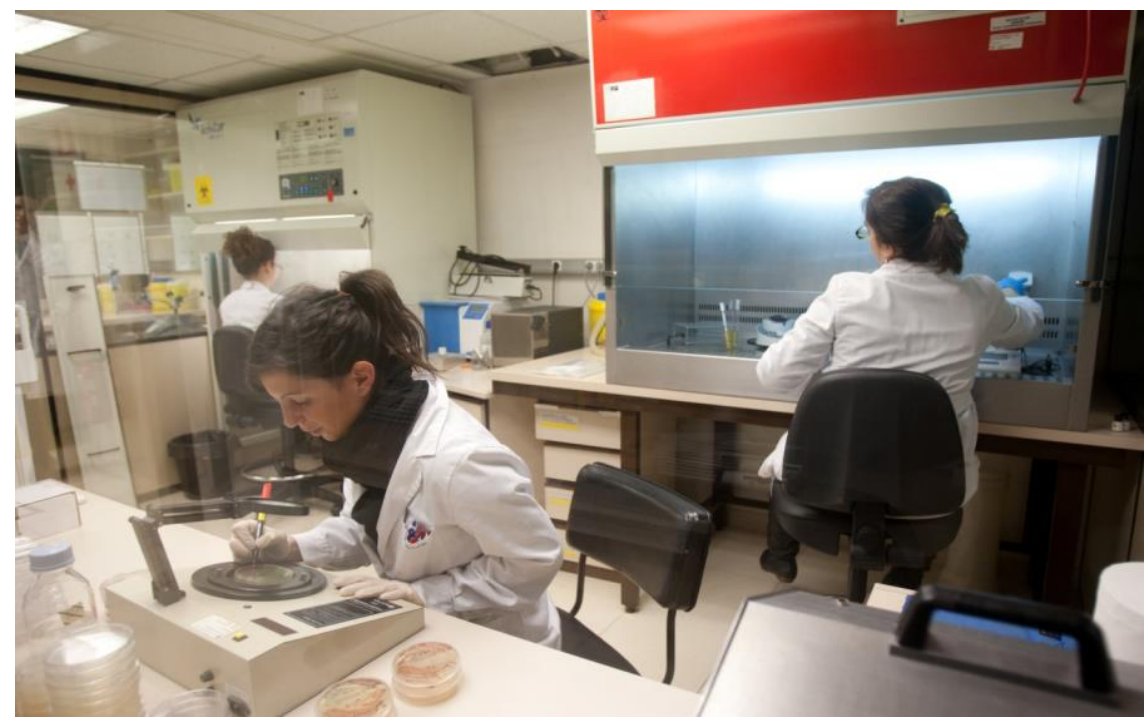

Figure 2. Laboratory of Pharmacology and Toxicology

2.1.3. Quality Assurance Services (Good Laboratory Practices, GLP)

The use of animals and toxicology make it necessary to include a unit dedicated to GLP's which guarantees, according to state-of-art, that all the work being carried out is done properly. In addition, this Quality Assurance
Services handles all accreditations so that any work that is done is recognized internationally, without the need to repeat the scientific investigation.

The work involved in this service includes drug registration in the officially authorized systems, at both national and international levels.
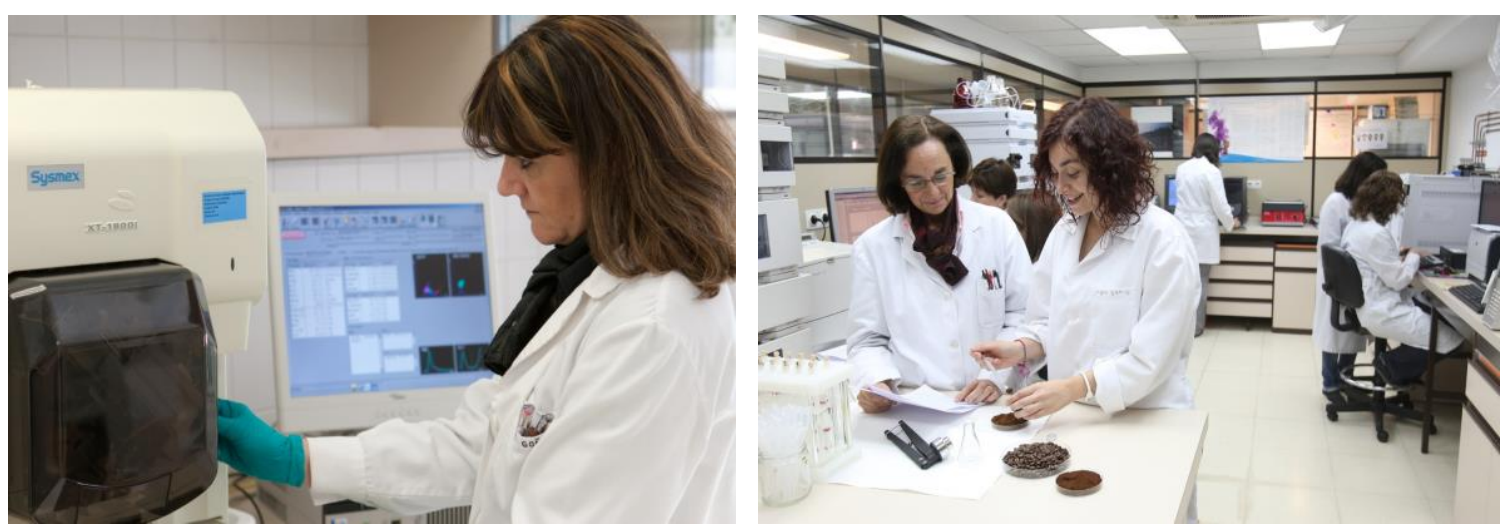

Figure 3. (Left and Right) Laboratory of Food and Water Microbiology 


\subsubsection{Instrumental Techniques Services}

In addition to the activity of a drug, it is necessary to understand its possibilities of absorption, distribution, metabolism, excretion and toxicology (ADMET), all of which need important techniques such as diverse types of chromatography, mass spectrometry, etc. The determination of biological activities is carried out in different departments and services. In CIFA, the use of large instrumental apparatuses is contemplated for their application in ADMET.
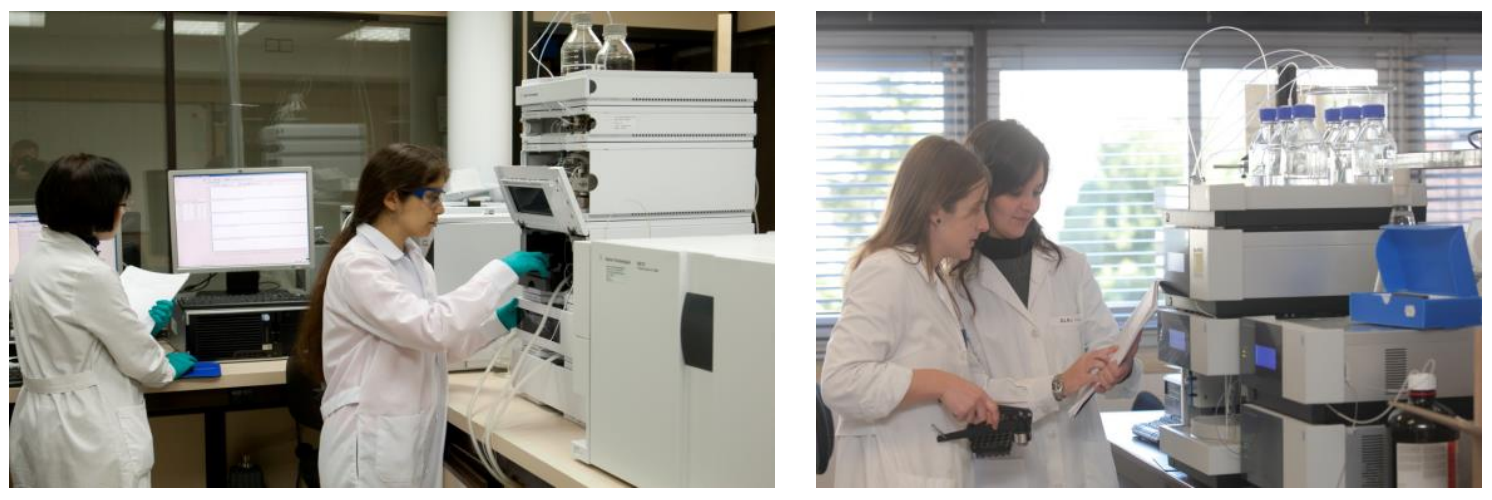

Figure 4. Laboratory of Instrumental Techniques

\subsection{Business and Project incubators}

In the modern work involved in Research \& Development \& Innovation (R\&D\&I), the project is decisive. The project can be internal or external. It involves a center being able to accommodate this project. Three situations are produced:

2.2.1. Project carried out in the center, using its own services

Project belonging to the UN or to companies. All material, personnel and other resources are from the center. One such example is that of the toxicology services.

\subsubsection{Interrrelated projects}

A part or the totality of a project is carried out outside of CIFA. The center coordinates the related activities of the entire project.
2.2.3. Project carried out in the center, under the direction of the party requesting CIFA services

CIFA offers its space and services to companies or to researchers from the UN when they request it for the realization of their projects.

\subsection{Specialized teaching}

CIFA, taking advantage of its global knowledge of medicinal agents, started up the Master in R\&D\&I of Novel Drugs (MIDI), carried out within its center in collaboration with the Faculty of Pharmacy of the UN, and presently in its XXIII edition. This Master program, which has been voted "the best Master program in its specialized category within Spain", lasts a period of sixteen months and has annual editions, taking in approximately 20 students from different parts of Spain as well as from diverse countries throughout the world.

The principal objective of this program is the R\&D\&l of new drugs and it covers the 
basic aspects of the business world. Important courses within the general study plan include activities which focus on the creation of companies.

The teachers giving the classes are specialized professionals from the University, Administration, and commercial pharmaceutical laboratories. Each student is assigned a tutor/counselor and carries out a $R \& D$ project in departments and specialized services of the UN or within collaborating companies.

\subsection{Project administration}

UN services are used, permitting the preparation of contracts, judicial aspects, patents, etc.

A system was established to cover the aspects dealing with the administration of resources and the contracting of personnel, always in support of the scientific management.

The patents which are generated from work carried out at CIFA are considered to be the property of the company which has paid for the project in terms of the economical aspect; the UN reserves itself for the corresponding intellectual property.

In all the agreements made with companies, contracted by CIFA, the researcher's right to publish project results is recognized. A clause is included in the contract which specifies the times and circumstances to be adhered to regarding publication of the work, always to be carried out in a positive light. The company authorizes or carries out patent processes in a pre-established time period. The same policy is used when the work project has originated in the UN. Up to now, no problems have ever arisen regarding publications, seminars, doctoral theses, etc.

The organizational structure of CIFA is based on a director of the center who, principally, is a scientific director, leaving the questions deal ing with contracting personnel for the center, economical aspects, safety issues, etc. in the hands of the general services of the UN. In this way, an optimal use of resources is attained and duplicity of organizational aspects is avoided. CIFA depends on a hierarchical structure which consists of the Vice President for research, and it consults and follows the indications given by the Interfacultative College Board, consisting of the Deans from the Faculties of Sciences, Medicine and Pharmacy. The principal challenge in this structure is recognizing the interests of the UN in general, and the needs and particularities of the different faculties.

The center supports itself as a result of the contracts it obtains and from billing for services rendered to the different companies as well as to the centers and services in the UN. All budget surplus situations that occur are reinvested in the UN. Normally, there is no budget deficit because all actions are adjusted to the existing needs.

\section{Final Considerations}

CIFA is a social good and has been beneficial to the UN. This experience has permitted the successful realization of activities leading to drug innovation, not possible via the traditional form of organization and structure of the University, always dedicated to the search for an adequate drug that can serve the sick who are suffering.

Over the years, this center has corrected its initial approaches based on the new situations and possibilities that have arisen. One such case is that of the specialization in large animals for neuronal diseases or for cases involving organ transplant studies. The initial idea of working under GLP conditions has been maintained in other activities such as Phase I trials, initially carried out in CIFA and presently taking place at the University of Navarra Hospital. 
The principal aspect has been that of CIFA having its own building for carrying out project incubator activities and services, forming part of the UN structure, yet physically separated.

The possibility of being able to carry out accredited research is of great interest to companies, especially in the cases of toxicology. Accreditation is recognized as an essential aspect if the aim is to be able to register a drug and internationally validate the studies carried out, with the important effect of keeping the number of animals used in experimentation to a minimum.

The possibility of being able to easily provide extensive development packages such as design, synthesis and biological evaluation or toxicology and phase $I$ is a very attractive offer for businesses and this center has signed important contracts with laboratories from all over the world. The flexibility that this system offers is both appealing and highly regarded.

The University-Company relationship has permitted the possibility of carrying out research agreements over extended periods of time, such as in the case of SERVIER Laboratories of France, with whom diverse research projects have been developed, involving depression, sleep disorders and obesity, linking together the projects and maintaining an adequate number of personnel and services.

CIFA's relationship with companies as incubators is an important part of center's history and an important example to cite is the center's collaboration with VISCOFAN, a company dedicated to cellulose and collagen for meat casings and medical applications, a relationship that has been maintained since the center was founded, stably employing seven persons, including doctorates, licentiates and technicians. The beginnings of this company, which coincided with the birth of CIFA, employs over 5,000 persons throughout the world, with the UN as the center of technological development of reference.

The organization of the center includes a scientific director as management; an executive secretary, who is also the secretary of the Master program and is in charge of assisting the public, suppliers and other services too; a technical secretary, in charge of all the aspects related with the English language, including translations of scientific reports, articles proposed for publication and any other language services required by the researchers; a maintenance employee who resolves the day-by-day problems that might arise within the building; and the general services of the UN when necessary. With the dedication of these people, this center is open continually from Monday through Friday, during the entire year.

Bear in mind that a center with these characteristics is a center of services and that the center's most important mission is precisely that of serving, in a double sense, carrying out quality work projects and being useful to almost 100 researchers who work directly in the center, to others who work within the UN and to the contracting companies.

This center's policy focuses on commitment and freedom. Only those who wish to be here are here and the center is against no one. The idea is to unite the efforts of those that want to be on the project. The most important person of this system is the researcher, to whom the center is dedicated to help in the search for an innovating drug.

These 25 years of CIFA have provided an opportunity to learn many things associated with the University-Companies Relationship. We trust in the future. 